\title{
Comparative analysis of antioxidant and secondary metabolites contents in eight populations of Medicago ciliaris $\mathrm{L}$.
}

\author{
Abidi Sourour ${ }^{1+*}$, Jabri Cheima ${ }^{1 \dagger}$, Souissi Amir ${ }^{1,2}$, Ferchichi Marwa ${ }^{3}$, Zoghlami-Khélil Aziza ${ }^{1}$ \\ 1 National Institute of Agronomic Research of Tunisia (INRAT), Laboratory of Animal and Forage Production, University \\ of Carthage, Street Hedi Karray, Al Manzah, 1004, Tunis, Tunisia. \\ 2 National Institute of Agronomy of Tunisia (INAT), University of Carthage, 43 Avenue Charles Nicole 1082 Tunis, \\ Tunisia. \\ ${ }^{3}$ Higher Institute of Heritage Crafts of Tunis (ISMPT), University of Tunis, 10 Street Kélibia, Bab El Khadra, 1006 \\ Tunis, Tunisia. \\ *: Corresponding author at: INRAT, Laboratory of Animal and Forage Production, University of Carthage, Street Hedi \\ Karray, Al Manzah, 1004, Tunis, Tunisia. \\ E-mail address: sourour.abidi@yahoo.fr. (S. Abidi). \\ $\dagger$ : Abidi Sourour and Jabri Cheima have contributed equally to manuscript writing
}

Keywords: Medicago ciliaris L., biochemical composition, antioxidant compounds, secondary metabolites,

Publication date 30/09/2019, http://www.m.elewa.org/JAPS

\section{$1 \quad$ ABSTRACT}

To identify the suitable genetic resources of forage legumes for animal feeding, the characterization of their chemical and biochemical composition is crucial since forage quality is a limiting factor which affects animal health and performance and consequently human health. In this context, this study carried out for the first time the analyses of the antioxidant compounds and the secondary metabolites (total phenols and tannins and saponins) in whole fresh biomass, flowers and stems of eight populations of Medicago ciliaris L (echinus Medicago) collected in different bioclimatic areas of north Tunisia. The analysis of variance showed significant differences between populations for all parameters $(\mathbf{P}<0.05)$ except for anthocyanins $(P>0.05)$. Significant correlations were found between carotenoids and chlorophylls $\mathrm{a}$ and $\mathrm{b}(\mathrm{r}=0.59, \mathrm{n}=48 ; \mathrm{P}<0.0001)$ and between lycopene and $\beta$ carotene $(r=0.81, n=48 ; P<0.0001)$. Multivariate analysis showed that populations 306 and 326 had the highest contents of chlorophyll a and carotenoids while Pop3 had the highest content of lycopene, $\beta$-carotenes, saponines and total tannins. These populations will be integrated in a breeding program for quality improvement of forage and will serve for grazing of pods and straw in summer and grazing of green biomass in winter and spring accordingly to their richness in antioxidant compounds.

\section{INTRODUCTION}

Tunisian flora is particularly rich in legumes species which have great agricultural and pastoral potential since they are used for food and livestock fodders. Generally, the Medicago species are large-seeded (Piano and Francis, 1992) (photo 1), indicating some benefit for seedling emergence and root penetration in soils subject to compaction such as clay soils (Piano and Pecetti, 2010). The Medicago species are abundant among legumes species (Zoghlami et al., 1996) and appreciated by animals. They serve as soil conditioning crops in addition to 
their medicinal applications. The Medicago species contain particular secondary metabolites such as coumarins, isoflavones and saponins (Barnes et al., 2007). They also synthesize a variety of bioactive natural products that are used to engage into symbiotic interactions and also serve to deter pathogens and herbivores (Gholami et al., 2014). In this context and for the identification of suitable genetic resources for animal feeding, the characterization of forage legumes for their antioxidant compounds and nutritional value is essential since forage quality is a limiting factor which affects both animal health and products and consequently human health. This interaction was demonstrated by scientific research highlighting the significant effects of several natural biochemical compounds of plant species against various human diseases (Elsayed Edriss et al., 2012). Several Medicago species are used in medicine, human food, green manure, and source of industrial enzymes in biotechnology (Gholami et al., 2014). In general, legumes are phytochemicals promoters and the exploitation of their natural antioxidants and secondary metabolites has been the subject of several research works. The chlorophyll, due to its green colour, is the main pigment contained in the chloroplasts of the plant cells. It is essential for the photosynthetic activity of the plant. Chlorophylls $\mathrm{a}$ and $\mathrm{b}$ are the most common in higher plants and in algae. They have a wide application in pharmacy, cosmetics and veterinary medicine. Chlorophyll derivatives accelerate tissue regeneration and have antimicrobial properties (Doss et al., 2011). Like polyphenols, carotenoids are part of the micronutrients that contribute to the body's defences against reactive oxygen species. The anthocyanins are flavonoids that attract pollinators and benefit both plant and human health (Pang et al., 2009). A moderate amount of these compounds is important in forage plants by protecting ruminants from bloating. According to Doss et al., (2011), saponins are glycosides occurring widely in plants. They are abundant in many foods consumed by animals and human, recognized for several biological properties (Rupasinghe et al., 2003; Doss et al., 2011) and nutritional and cosmetics attributes (Doss et al., 2011). Nevertheless, none is known about the antioxidant compounds in Medicago ciliaris L. and their beneficial effect on animal health and product. In this frame and for a better valorization of pasture and forage legumes genetic resources in animal feeding, investigation of chemical composition, antioxidant compounds and secondary metabolites in fresh and dry biomass of eight populations of Medicago ciliaris L. has been carried out. 

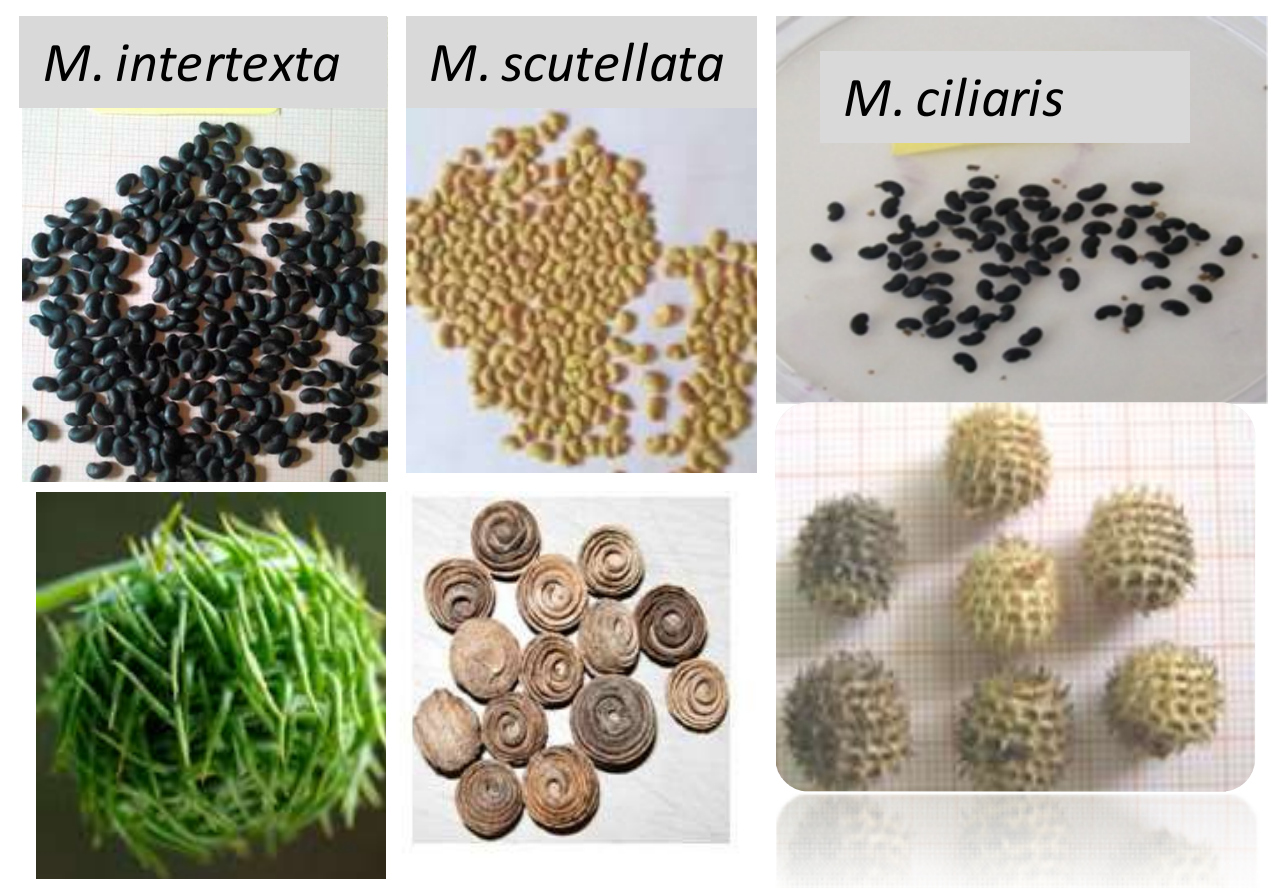

Photo 1: Seeds (above) and corresponding pods (below) of some Medicago species ‘

\section{MATERIALS AND METHODS}

3.1 Origin of populations and field experiment: The plant material used is represented by eight populations of Medicago ciliaris L. selected on the base of their genetic diversity (Jabri et al., 2017). These populations were collected in different regions of Northern in both National Institute of Agronomic Research of Tunisia (INRAT) and the National Genes Bank of Tunisia (BNG). The environmental characteristics at the collection sites of the studied $M$. ciliaris L. populations are Tunisia in 1992, 1994 and 2009 and preserved listed in Table 1.

Table 1. Environmental characteristics at the collection sites of the studied M. ciliaris L. populations (Jabri et al., 2016).

\begin{tabular}{lllllllllll}
\hline Site [population] & $\begin{array}{l}\text { Year of } \\
\text { collection }\end{array}$ & $\begin{array}{l}\text { Annual } \\
\text { rainfall } \\
(\mathbf{m m})\end{array}$ & $\begin{array}{l}\text { Elevation } \\
(\mathbf{m} . \mathbf{a . s . 1 )}\end{array}$ & $\begin{array}{l}\text { Min } \\
\mathbf{T} \\
\left({ }^{\circ} \mathbf{C}\right)\end{array}$ & $\begin{array}{l}\text { Total } \\
\mathbf{C a O}_{3} \\
(\mathbf{9})\end{array}$ & $\begin{array}{l}\mathbf{O M} \\
(\mathbf{\%})\end{array}$ & $\begin{array}{l}\mathbf{p H} \\
\mathbf{E C} \\
\mathbf{M m h o} \\
\text { /cm) }\end{array}$ & $\begin{array}{l}\mathbf{N} \\
(\mathbf{p p m})\end{array}$ & $\begin{array}{l}\mathbf{P}_{2} \mathbf{O}_{5} \\
(\mathbf{p p m})\end{array}$ \\
\hline Siliana [306] & 1992 & 341.1 & 575 & 1.6 & 53.85 & 2.38 & 8.1 & 0.27 & 1075 & 2.9 \\
Oued Messouge [326] & 1992 & 367.1 & 500 & 1.6 & 27.68 & 1.51 & 8.0 & 0.28 & 1043 & 3.4 \\
Dougga [355] & 1992 & 493.5 & 320 & 9.9 & 65.89 & 1.98 & 8.0 & 0.24 & 765 & 2.1 \\
Ghzala [660] & 1994 & 554.2 & 5 & 6.7 & 42.30 & 2.50 & 7.9 & 1.01 & 1044 & 13.3 \\
Zana [861] & 1994 & 507 & 10 & 6.7 & 44.20 & 1.82 & 8.0 & 1.12 & 1064 & 23.3 \\
Raoued El Hessiane [Pop1] & 2009 & 398.5 & 6 & 5.4 & 52.60 & 2.84 & 7.6 & 0.41 & 430 & 22.6 \\
Kalaat Andalous [Pop2] & 2009 & 398.5 & 6 & 5.4 & 54.30 & 1.16 & 7.2 & 0.16 & 160 & 26.6 \\
Ghar El Melh [Pop3] & 2009 & 497.8 & 6 & 6.7 & 54.30 & 1.16 & 7.2 & 0.16 & 160 & \\
\hline
\end{tabular}

m.a.s.l: $\mathrm{m}$ above sea level; Min T: minimum temperature $\left({ }^{\circ} \mathrm{C}\right)$; OM: organic matter; EC: electric conductivity; N: nitrogen

The populations were sown in the experimental field at INRAT during the growing season (2015-2016). The experimental field is located in the semi-arid area in north Tunisia with 426 $\mathrm{mm}$ as average annual rainfall and $9.8^{\circ} \mathrm{C}$ and $34.2^{\circ} \mathrm{C}$ as minimum and maximum air 
temperatures, respectively. The experimental design consisted of one row of $1 \mathrm{~m}$ long spaced $50 \mathrm{~cm}$ apart replicated three times. The sowing operation was done in November 2015 using a seeding rate of $15 \mathrm{~kg} \mathrm{ha}^{-1}$. Seeds were previously scarified using sand paper in order to ensure a homogeneous germination. Weeds were manually removed and a supplemental irrigation was provided during plant establishment and spring.

\subsection{Laboratory measurements}

3.2.1 Samples preparation: In order to determine the chlorophylls a and b, lycopenes and carotenoids contents, a $500 \mathrm{~g}$ sample of fresh biomass was taken from each line and replication at flowering stage time. For $\beta$ carotene and anthocyanins determination, a random sampling of 30 flowers and $100 \mathrm{~g}$ of fresh stems per population and replication was done, respectively. For secondary metabolites determination (phenols, tannins and saponins), a $500 \mathrm{~g}$ sample of fresh biomass (leaves and stems) was taken from each row and replication and dried in an oven for $72 \mathrm{~h}$ at $40^{\circ} \mathrm{C}$.

3.2.2. Determination of dry matter content (DM): The dry matter content was determined according to AOAC (1990) and only ground samples of dry biomass were used for dry matter determination. This data is used in the calculation of the secondary metabolites.

\subsubsection{Determination of antioxidant} compounds: The method of Nagata and Yamashita (1992) was used for the determination of the antioxidant compounds (chlorophylls a and b, lycopenes, carotenoids,

\section{RESULTS}

4.1 Dry matter content (DM): The analysis of variance showed that the dry matter content in fresh biomass did not vary significantly between populations $(\mathrm{P}>0.05)$. It ranged from $17.4 \%$ for population 306 to $21.4 \%$ for population 861 with an average of 19.5\%. Populations 660, 355, 326 and 861 exceeded the total mean and their average being of 19.6, 20, 21 and 21.2\% of DM, respectively. anthocyanins, and $\beta$-carotene). The $\beta$-carotene was determined on flowers, the anthocyanins on stems and the lycopenes, the chlorophylls a and $b$ and the carotenoids on fresh biomass (stems and leaves). For the carotenoids and anthocyanins determination, the method of Lichtenthaler and Welburn (1983) was performed while the method of Sims and Gamon (2002) was carried out for anthocyanins determination.

3.2.4 Determination of secondary metabolites: Secondary metabolites involved total phenols, tannins and saponins. The determination of total phenols and tannins was carried out according to Makkar (2000) and their contents are expressed in tannic acid equivalent $/ \mathrm{kg}$ of dry matter. While for saponins content, the method of Hiai et al., (1976) was used and the contents are expressed in diosgenin equivalent $/ \mathrm{kg}$ of dry matter.

3.3 Statistical analysis: A one-way Analysis of variance (ANOVA) was performed to assess the variation of the biochemical traits with "population" and "replicates" as fixed effects. Data were analysed using the General Linear Model (SAS. 2002). For comparing treatment group means, the Duncan test was used at 5\% of significance. Pearson correlations between the measured parameters were calculated. Principal Component Analysis (PCA) and Cluster Analysis (CA) were also applied to the significant variables determined for $M$. ciliaris $\mathrm{L}$. populations using $\mathrm{JMP}^{\circledR} 11.0$ (SAS Institute. 2014).

4.2 Antioxidants compounds: In this article, we report for the first time, the analysis of antioxidant compounds in whole biomass, flowers and stems of eight populations of $M$. ciliaris L. This pasture legume is being widely distributed in Mediterranean basin and in similar climates. The analysis of variance showed a significant effect of populations on all the compounds except anthocyanins (Table 2). 
Table 2: Results of the analysis of variance applied to the antioxidant parameters analysed in the eight populations of $M$. ciliaris $\mathrm{L}$.

\begin{tabular}{l|l|l}
\hline Part of the plant & Parameters & P value \\
\hline \multirow{2}{*}{ Fresh Biomass } & Chlorophyll a & $0.0143^{*}$ \\
\cline { 2 - 3 } & Chlorophyll b & $0.0001^{* * *}$ \\
\hline & Lycopenes & $0.0007^{* * *}$ \\
\hline Flowers & Carotenoids & $0.0002^{* * *}$ \\
\hline Stems & $\beta$-carotenes & $<0.0001^{* * *}$ \\
\hline & Anthocyanins & $0.2988 \mathrm{~ns}$ \\
\hline
\end{tabular}

*: significant at $5 \%$ level; ***: significant at $0.1 \%$ level; ns: not significant at $5 \%$ level.

Concerning chlorophylls $a$ and $b$, the population 326 had the highest content (Figure 1A) while for carotenoids, the population 306 is the richest one (Figure 1B). Chlorophyll $\mathrm{a}$ is high in population $326(5.08 \mathrm{mg} / \mathrm{g} \mathrm{DM})$ and low in Pop3 $(2.46 \mathrm{mg} / \mathrm{g} \mathrm{DM})$ with an average of $3.6 \mathrm{mg} / \mathrm{g}$ DM. Chlorophyll $\mathrm{b}$ is lower than chlorophyll a and varied widely between populations: it ranged from $0.34 \mathrm{mg} / \mathrm{g} \mathrm{DM}$ in Pop1 to $3.29 \mathrm{mg} / \mathrm{g}$ DM in population 326 with an average of $1.9 \mathrm{mg} / \mathrm{g}$ DM. The carotenoids ranged from $0.6 \mathrm{mg} / \mathrm{g}$ DM in each of Pop1, Pop2 and Pop3 to $1.9 \mathrm{mg} / \mathrm{g} \mathrm{DM}$ in population
306 with an average of $1.3 \mathrm{mg} / \mathrm{g}$ DM. These levels were higher than those of hairy vetch $(0.4$ $\mathrm{mg} / \mathrm{g} \mathrm{DM})$ and Sulla $(0.16 \mathrm{mg} / \mathrm{g} \quad \mathrm{DM})$ cultivated in the same field and used for comparison. The $\beta$-carotene and lycopene contents were generally very low. The former varied from $0.01 \mathrm{mg} / \mathrm{ml}$ for Pop1 to 0.22 $\mathrm{mg} / \mathrm{ml}$ for Pop3 with an average of 0.08 $\mathrm{mg} / \mathrm{ml}$ while the latest one varied from 0.01 to $0.16 \mathrm{mg} / \mathrm{g}$ DM for Pop1 and Pop3 respectively, with an average of $0.06 \mathrm{mg} / \mathrm{g} \mathrm{DM}$ (Figure 1C, 1D). 
A)

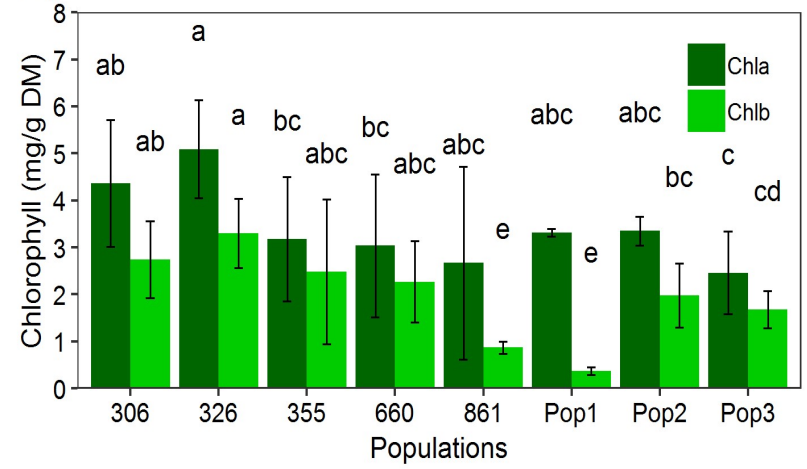

C)

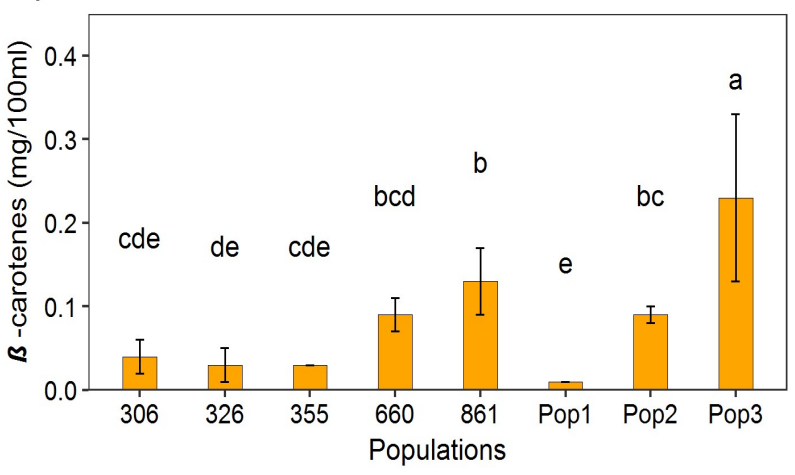

B)

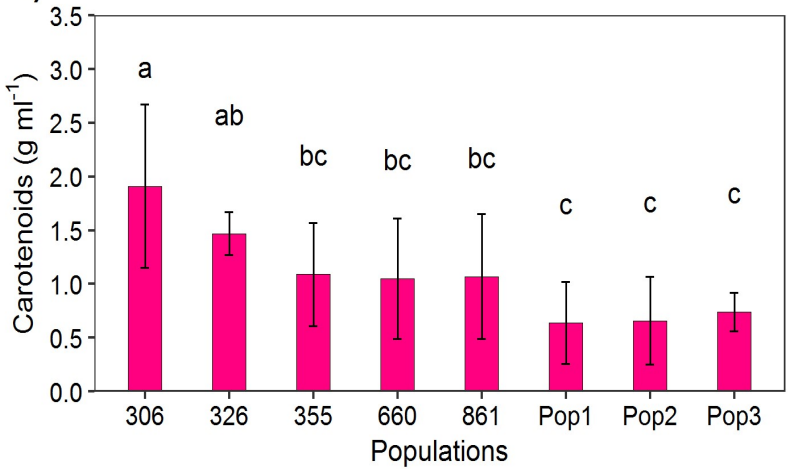

D)

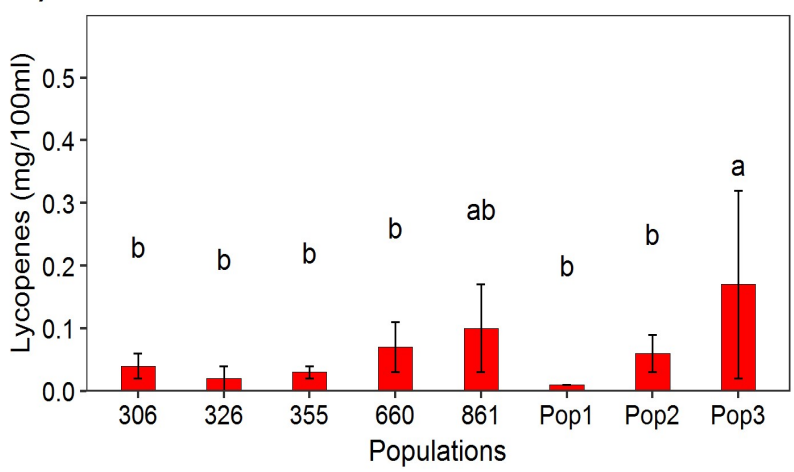

Figure 1. Variation of chlorophylls a and b (A) and carotenoids (B) $\beta$-carotenes (C) and lycopenes (D) among populations of $M$. ciliaris L. Different letters indicate significant differences at $\mathrm{p}<0.05$ according to Duncan test.

Strong and significant positive correlations were found between carotenoids and chlorophylls a and $\mathrm{b}(\mathrm{r}=0.59, \mathrm{n}=48 ; \mathrm{P}<0.0001)$ and between lycopenes and $\beta$-carotene $(\mathrm{r}=0.81, \mathrm{n}=48$; $\mathrm{P}<0.0001$ ) (Figure 2). 


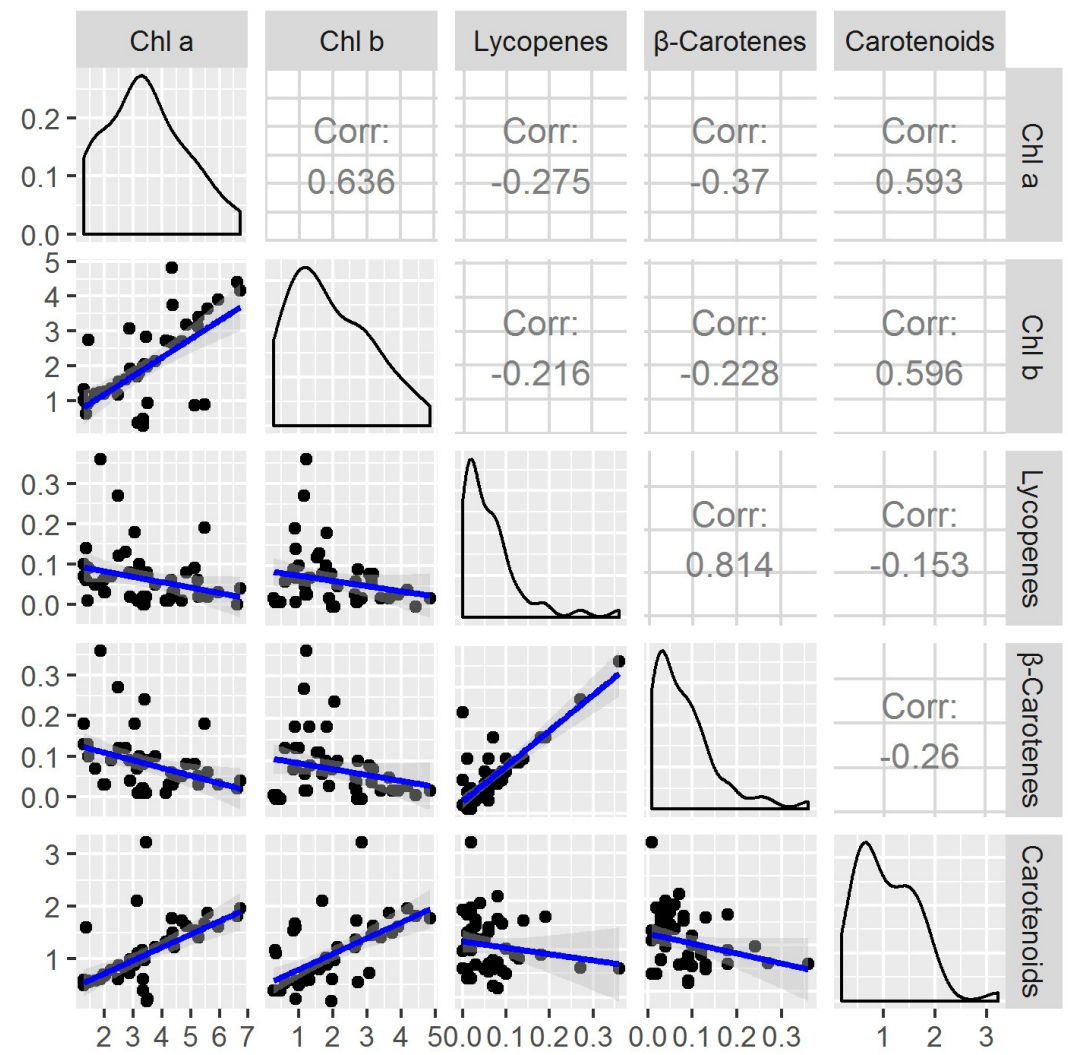

Figure 2. Pearson correlation among anti-oxidant compounds (chlorophylls a and b, $\beta$-carotenes, carotenoids, and lycopenes).

4.3 Secondary metabolites: The analysis of variance showed a significant effect of populations $(\mathrm{P}<0.05)$ on total phenols and tannins and saponins contents (Table 4).

Table 4. Secondary metabolites content in the eight populations of M. ciliaris $\mathrm{L}$.

\begin{tabular}{lll}
\hline Part of the plant & Parameters & P value \\
\hline Dry Biomass & Total Phenols & $0.0396^{*}$ \\
& Total Tannins & $0.0004^{* * *}$ \\
& Saponins & $0.019^{*}$ \\
\hline
\end{tabular}

*: significant at $5 \%$ level; ${ }^{* *}$ : significant at $1 \%$ level; ${ }^{* *}$ : significant at $0.1 \%$ level

Total phenols ranged from $15.6 \mathrm{~g}$ eq of tannic acid in each of Pop1 and Pop3 to $25.8 \mathrm{~g}$ eq of tannic acid for each of population 355, 326 and 660 with an average of $20.81 \mathrm{~g}$ eq of tannic acid (Figure 3A). While total tannins varied from 6.25 to $14.5 \mathrm{~g}$ eq. tannic acid for populations 355 and Pop3, respectively (Figure 3B) with an average of $8.6 \mathrm{~g}$ eq. tannic acid. 

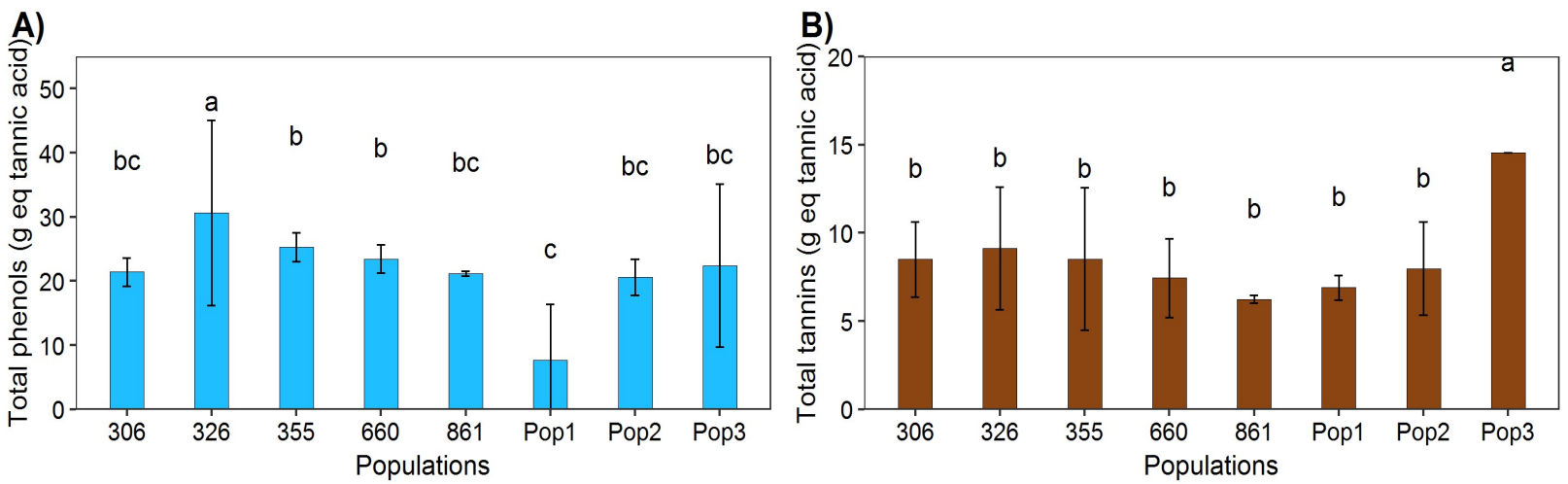

Figure 3. Total phenols (A) and tannins (B) contents in the dry matter of $M$. ciliaris L populations. Different letters indicate significant differences at $\mathrm{p}<0.05$ according to Duncan test.

According to figure 4, Pop3 (coastal area) had the highest content of saponins $(0.28 \mathrm{~g}$ eq dios $/ 0.25 \mathrm{ml}$ ) while population 861 (low coastal area) had the lowest one $(0.14 \mathrm{~g}$ eq dios $/ 0.25 \mathrm{ml}$ ). The population 355 (inland area) and Pop3 exceeded the overall average $(0.21 \mathrm{~g}$ eq $\operatorname{dios} / 0.25 \mathrm{ml})$.

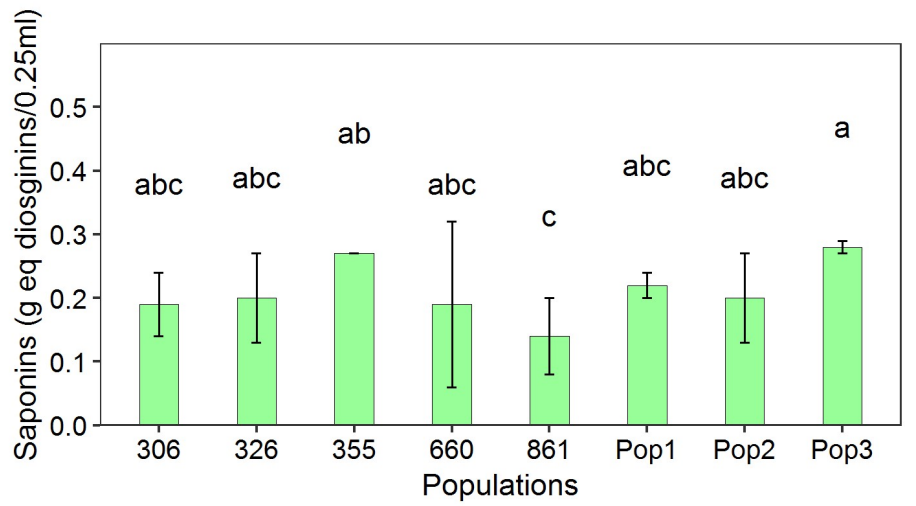

Figure 4. Variation of saponins contents in the dry matter of $M$. ciliaris L populations. Different letters indicate significant differences at $\mathrm{p}<0.05$ according to Duncan test.

The principal components analysis applied to all significant variables showed that the first 3 axes absorbed $85 \%$ of the total variation; axis 1 , axis 2 and axis 3 absorbed $50.4 \%, 21 \%$ and $13.6 \%$ of the total variation, respectively. Axis 1 was defined on the positive side by chlorophyll $\mathrm{a}$ and by lycopenes and $\beta$-carotene on the negative side while axis 2 was defined by saponins and chlorophyll $\mathrm{b}$ on the positive side. Axis 3 was defined by saponins on the negative side. The distribution of the populations according to the factorial plan (1-2) showed three groups of populations: a group formed by populations 306 and 326 with the highest contents of chlorophyll a and carotenoids which opposed Pop3 with the highest contents of lycopenes and $\beta$-carotenes. The third group contained the rest of populations (Pop1, Pop2, 355, 660 and 861) which were intermediate or poor in these substances (Figure 5). 


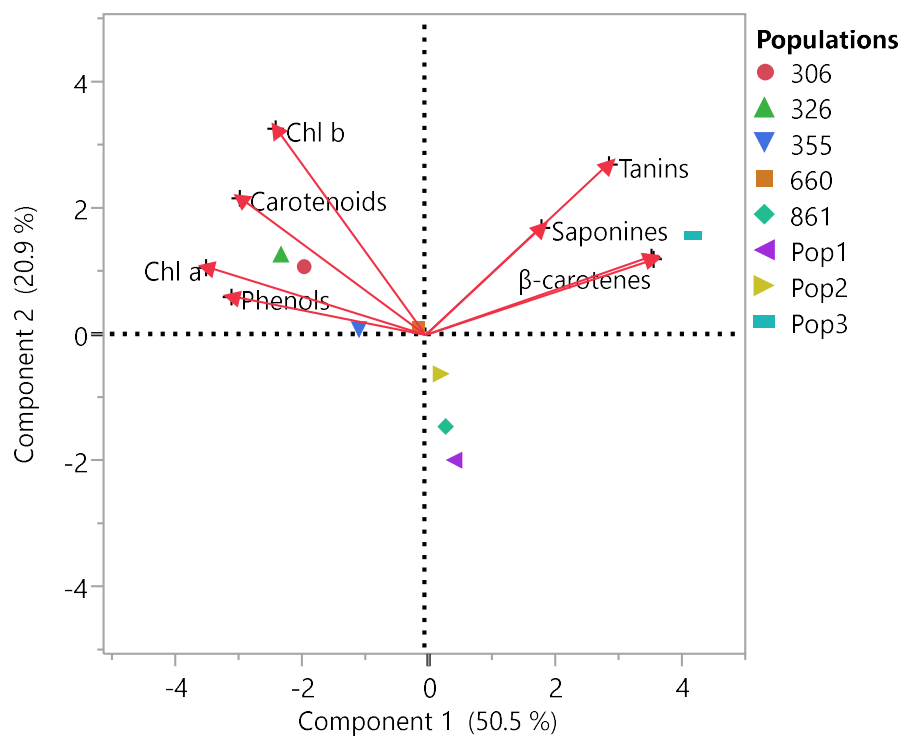

Figure 5. Biplot (1-2) of PCA applied to significant biochemical parameters determined on fresh biomass and flowers of $M$. ciliaris L. populations.

Cluster analysis showed three groups of populations: the first one gathering populations 306 and 326 which are similar, the second containing Pop3 which is the most distant one and a third group containing the rest of populations (Figure 6).

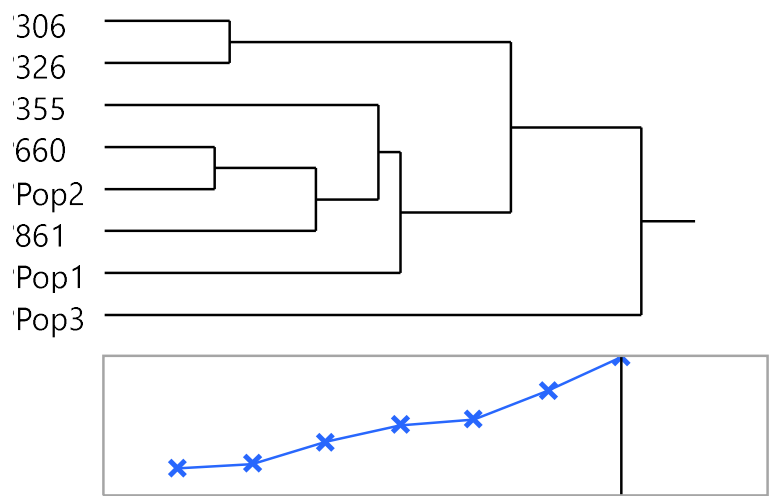

Figure 6. Dendrogram established according to the cluster analysis (CA) applied to the significant biochemical parameters determined on fresh biomass, stems and flowers of the M. ciliaris L. populations

\section{DISCUSSION}

In the present research work, the antioxidant compounds and the secondary metabolites in $M$. ciliaris were studied for the first time. The populations exhibited different types of antioxidant compounds and secondary metabolites. The knowledge of those constituents is paramount, a feature possibly reflecting some advantage for the synthesis of chemical complex substances. The screening of various plants for phytochemicals was reported by several authors (Siddiqui et al., 2009; Savithramma et al., 2011). Preliminary phytochemical quantitative analysis of $M$. ciliaris populations for chlorophylls, $\beta$-carotene, carotenoids, total phenols and tannins contents and saponins revealed a large variation among 
population for all these compounds. The chlorophylls, as a primary metabolite, are widely distributed in nature and play a key role in metabolic processes such as photosynthesis, respiration and nutrient uptake (Geetha and Geetha, 2014). The values reported in this study for chlorophylls a and $b$ are higher than those reported by Jabri et al., (2016) but lower than those reported by Haffani-Ksontini (2015). According to Devmalkar et al., (2014), total chlorophyll varied with seasons and light intensity. Carotenoids and flavonoids are involved in cell pigmentation in flowers and seeds, seed dispersers and plant reproduction (Pagare et al., 2015). Carotenoids are important in photosynthesis apparatus where they interfere by protecting chlorophyll from heat and solar radiation. Indeed, in the current study, the strong and significant positive correlations obtained between carotenoids and chlorophylls $\mathrm{a}$ and $\mathrm{b}$ support this hypothesis. Furthermore, the highest concentrations of carotenoids are present in green grass grazed in spring and autumn than in late-stage grass with the lowest concentrations (Calderon et al., 2007). Our results showed that Pop3 (from coastal area) had the lowest content of carotenoids $(0.63 \mathrm{~g} / \mathrm{ml})$ while population 306 (from high inland area) had the highest content $(1.9 \mathrm{~g} / \mathrm{ml})$. These contents are higher than those revealed by Farrugia et al., (2008) (0.43 to $0.7 \mathrm{mg} / \mathrm{g} \mathrm{DM}$ ) in green herb of permanent grassland. For $\beta$ carotenes in flowers, the levels reported in this study are so small compared to those of alfalfa and yellow clover $(0.08 \mathrm{mg} / \mathrm{ml}$ vs. $26-33 \mathrm{mg} \mathrm{kg}$ $\left.{ }^{1} \mathrm{DM}\right)$ and those of clover bird's feet (0.08 $\mathrm{mg} / \mathrm{ml}$ vs. 56-61 mg kg-1 DM). Anthocyanins offer benefits for human and animal health. Dietary anthocyanins have been associated with improving the risk factors for chronic diseases. Their content varied considerably from species to species. Even the values of anthocyanins reported in this study for $M$. ciliaris populations are very low (an average of 0.02 moles $/ \mathrm{ml}$ ), they may be useful in animal health. Secondary metabolites are organic molecules synthesized by plants from primary metabolites through various ways. They include saponins which exhibit anticholesterolemic, anti-cancer, adjuvant and haemolytic activities (Gholami et al., 2014) and total phenols and tannins. Polyphenols have multiple interests because of their ability to regulate the expression of certain genes or their specific distribution in plants which allow them to be good markers in terms of animal feed traceability. Moreover, phenolic compounds may have a signalling role (Treutter, 2006), i.e. the establishment of symbiosis between Fabaceae and bacteria, which allows these plants to directly fix atmospheric nitrogen. They participate in pollination phenomena since they are responsible for the colouring of flowers (Macheix et al, 2005) and in the resistance to biotic and abiotic stresses (Guitton, 2010). Their content depends on the species, the variety and the conditions of cultivation. The levels of saponins obtained in this study for $M$. ciliaris populations are higher than those reported for alfalfa (21\% vs. $2-3 \%)$ (Barnes et al., 2007). M. truncatula has various saponins contents (Huhman and Sumner. 2002). The average total phenols content obtained in this study for $M$. ciliaris is higher than that obtained for $M$. truncatula and $M$. minima (20.8g eq. tannic acid vs. 10.4 g. eq tannic acid/kg of DM for each, respectively) and for Astragalus bamosus and Coronilla scorpioides (9.7 and $6.6 \mathrm{~g}$ eq. tannic acid $/ \mathrm{kg}$ of DM, respectively) (Zoghalmi et al., 2005). The same observation was obtained with total tannins (8.6 vs. 7.5 eq tannic acid $/ \mathrm{kg}$ of DM, for both $M$. truncatula and M. minima) and (8.6 vs. 4.6 and 3.8 eq tannic acid/ $\mathrm{kg}$ of DM for $A$. hamosus and $C$. socrpioides, respectively). It seems that the tannin richness is correlated with the genotype and several herbaceous and shrubby forage species have shown variability for this parameter. According to PCA, two groups of populations were observed, the group of 306 and 326 (both from inland area) characterized by their richness in chlorophyllian pigments and carotenoids and that of Pop3 (from coastal area) which is distinguished by its richness in lycopenes, $\beta$-carotenes and saponins. 


\section{CONCLUSION}

This study presents new information on the biochemical characterization of different plant part of Medicago ciliaris L. and confirms the important potential of these unexploited genetic resources for improving animal health products. Indeed, the results showed differences between populations for several parameters. Based on the presence of variety of phytochemicals in the plant parts of M. ciliaris, the grazing of biomass and pods of this species is recommended for the growth of sheep and their well-being. Furthermore, breeding strategies exploiting the existing natural

\section{REFERENCES}

AOAC: 1990. Official methods of analysis of the Association of official analytical chemists. Edited by Kenneth Helrich, $15^{\text {th }}$ ed. Published by the Association of Official Analytical Chemists, INC. USA.

Barnes J, Anderson LA and Phillipson JD: 2007. Chemical Constituents of Plants Used as Herbal Medicines, in: Herbal Medicines. Third Edition. Pharmaceutical Press; London. pp: 2841. ISBN 9780853696230.

Devmalkar VS, Murumkar CV, Salunkhe SM and Chavan SJ: 2014. Studies on pigment chlorophyll isolation and estimation of different bryophytes for their biochemical properties. Journal of Natural Product and Plant Resources. 2: 56-61.

Doss A, Parivuguna V, Vijayasanthi $M$ and Surendran S: 2011. Antibacterial evaluation and phytochemical analysis of Medicago sativa L. against some microbial pathogens. Indian Journal of Science and Technology. 4 (5): 550-552. ISSSN: 0974- 6846.

Elsayed Edriss A, Alfadil Abjar Z and Abdelrahim Satti A: 2012. Phytochemical screening of important secondary metabolites in some extracts variation among $M$. ciliaris can be used to produce forages or foods enhanced with different phytonutrients. Nevertheless, for food security and active and healthy life, the development of plant research that address how plant-based foods contribute to human health is needed. In perspectives, it is essential to promote these populations by animal grazing of pods and straw in summer and green biomass in winter and spring according to their richness in antioxidant compounds and thereby to include them in selection programs.

of two Sudanese plants. Global Advanced Research Journal of Environmental Science and Toxicology, 1 (8): 199-202. ISSN: 2315-5140.

Geetha TS and Geetha N: 2014. Phytochemical screening, quantitative analysis of primary and secondary metabolites of Cymbopogan citratus (DC) stapf. leaves from Kodaikanal hills, Tamilnadu. International Journal of PharmTech Research CODEN (USA). 6 (2): 521529.

Guitton Y: 2010. Diversité des composés terpéniques volatils au sein du genre Lavandula: aspects évolutifs et physiologiques. Thèse de doctorat pour l'obtention du grade de Docteur en Sciences de l'Université de SaintEtienne-Jean-Monnet Discipline: Biologie et Physiologie Végétales, 255p.

Hiai S, Oura H and Nakajima T: 1976. Color reaction of some sapogenins and saponins with vanillin and sulfuric acid. Planta Med, 29 (2): 16-22.

Huhma DV and Sumner W: 2002. Metabolic profiling of saponins in Medicago sativa and Medicago truncatula using HPLC coupled to an electrospray ion-trap 
mass spectrometer. Phytochemistry. 59(3): 347-60.

Jabri C, Abidi S, Jouini L and Zoghlami Khélil A: 2016. Antioxidants and chemical composition of some local populations of Medicago ciliaris L. In: Options Méditerranéennes. Proceeding of the $15^{\text {th }}$ Meeting of the FAO-CIHEAM network on «Mediterranean forages and Forage crops». Orestiada/Greece. 12-14 April 2016. Seria A (114): 187-190. ISSN: 1016-121-X.

Jabri C, Sbei H, Zitouna N, Trifi-Farah $\mathrm{N}$ and Zoghlami Khelil A: 2017. Phenomorphological variation, genetic diversity and population structure of Tunisian Echinus Medic (Medicago ciliaris L.). Genetic and Molecular Research. 15 (3): 1-18. gmr.15038595.

Lichtenthaler HK and Wellburn AR: 1983. Determinations of total carotenoids and chlorophylls $\mathrm{a}$ and $\mathrm{b}$ of leaf extracts in different solvents, Biochemical Society Transactions. 11: 591-592.

Makkar HPS: 2000. Quantification of tannin assays for predicting and improving the safety and efficiency of feeding ruminants on tanniniferous tree foliage. FAO/IAEA working document. IAEA Vienna. 38p.

Nagata M and Yamashita I: 1992. Simple method for Simultaneous determination of chlorophyll and carotenoids in tomato fruit. Journal of Japanese society and Food science technology. 39 (10): 925-928.

Pagare S, Bhatia M, Tripathi N, Pagare S and Bansal YK: 2015. Secondary Metabolites of Plants and their Role: Overview. Current Trends in Biotechnology and Pharmacy. 9 (3): 293-304. ISSN 0973-8916 (Print): 22307303 (Online).

Piano E and Francis CM: 1992. The annual species of Medicago in the Mediterranean region. Ecogeography and related aspects of plant introduction and breeding. In: P. Rotili and L. Zannone (eds.). The future of lucerne. Biotechnology, breeding and variety constitution. ISCF, Lodi, Italy, pp: 373-385.

Piano E and Pecetti L: 2010. Minor Legume Species. In: Boller, B., Posselt, U.K., Veronesi, F. (eds.) Fodder Crops and Amenity Grasses. Handbook of Plant Breeding, vol 5. Springer, New York, NY. https://doi.org/10.1007/978-14419-0760-820.

Rupasinghe HP, Jackson CJ, Poysa V, Di Berado C, Bewley JD and Jenkinson J: 2003. Soya sapogenol A and B distribution in Soybean (Glycine max L.) Merr. in relation to seed physiology, genetic variability and growing location. Journal of Agricultural Food Chemistry. 51: 5888-5894.

SAS: 2002. SAS Institute. Base SAS 9.3 procedures guide: statistical procedures, Cary. NC. USA.

SAS Institute. 'JMP® 11. SAS Institute, 2014. JMP® 11 scripting guide' 2nd edit, SAS Institute Inc.: Cary. NC. USA.

Savithramma N, Rao L and Suhrulatha MD: 2011. Screening of Medicinal Plants for Secondary Metabolites. Middle-East Journal of Scientific Research. 8 (3): 579-584. ISSN 1990-9233.

Siddiqui S, Verma A, Rather AA, Jabeen F and Meghvansi MK: 2009. Preliminary phytochemicals analysis of some important medicinal and aromatic plants. Advanced Biological Research. 3 (5-6): 88-195.

Sims DA and Gamon JA: 2002. Relationships between leaf pigment content and spectral reflectance across a wide range of species, leaf structures and developmental stages. Remote Sensing of Environnement. 81: 337-354.

Treutter D: 2006. Significance of Flavonoids in Plant Resistance: A Review. Environmental Chemistry Letters. 4, 
147-157.

http:/ /dx.doi.org/10.1007/s10311-0060068-8.

Zoghlami A, Hassen H, Robertson L and Salkini AK: 1996. Distribution des luzernes annuelles en Tunisie centrale en fonction des facteurs édaphiques et climatiques. Fourrages, 145: 5-16.

Zoghlami Khélil A, Ben Salem H and Zouaghi M: 2005. Production et caractérisation nutritionnelle de deux légumineuses pastorales: Astragalus bamosus L. et Coronilla scorpioides L. Koch. Revue de l'INAT, 20 (1): 209-226. 